\title{
PENGARUH SUBSTITUSI ION Ti-Zn TERHADAP SIFAT KEMAGNETAN dan SIFAT PENYERAPAN GELOMBANG ELEKTROMAGNETIK MATERIAL SISTEM BaFe12-xTix/2Znx/2O19
}

\author{
Nenni $^{1, a)}$, Mutia Delina ${ }^{1, b)}$, Wisnu Ari Adi ${ }^{2, c)}$, Yana Taryana ${ }^{3)}$ \\ ${ }^{1)}$ Program Studi Fisika, FMIPA, Universitas Negeri Jakarta, Jl. Rawamangun Muka, Jakarta 13220 \\ ${ }^{2)}$ Pusat Sains dan Teknologi Bahan Maju, BATAN Kawasan Puspiptek, Serpong, Tangerang 15314 \\ ${ }^{3)}$ Pusat Penelitian Elektronika dan Telekomunikasi, LIPI Jl. Sangkuriang, Komplek LIPI, Kota Bandung, \\ Jawa Barat 40135
}

Email: a)nenni_gracia@yahoo.com, ${ }^{\text {b) }}$ mutia_delina@unj.ac.id, ${ }^{\text {c) } d w i s n u a a @ b a t a n . g o . i d ~}$

\begin{abstract}
Abstrak
Substitusi ion $\mathrm{Ti}^{+4}$ dan $\mathrm{Zn}^{+2}$ pada material magnetik $\mathrm{BaFe}_{12-\mathrm{x}} \mathrm{Ti}_{\mathrm{x} / 2} \mathrm{Zn}_{\mathrm{x} / 2} \mathrm{O}_{19}(\mathrm{x}=0$ dan 2) menggunakan metode wet milling telah dilakukan. Penelitian ini dilakukan untuk mengetahui pengaruh subtitusi Ti-Zn terhadap sifat magnetik dan penyerapannya. Material magnetik $\mathrm{BaFe}_{12-\mathrm{x}} \mathrm{Ti}_{\mathrm{x} / 2} \mathrm{Zn}_{\mathrm{x} / 2} \mathrm{O}_{19}$ disintesis dari campuran bahan oksida $\mathrm{BaCO}_{3}, \mathrm{Fe}_{2} \mathrm{O}_{3}, \mathrm{TiO}_{2}$ dan $\mathrm{ZnO}$. Campuran dimilling selama 5 jam, dikeringkan pada suhu $100^{\circ} \mathrm{C}$ kemudian disintering pada suhu $1000^{\circ} \mathrm{C}$ selama 5 jam. Hasil refinement dari pola difraksi sinar-X menunjukkan bahwa sampel memiliki fasa tunggal $\mathrm{BaFe}_{12} \mathrm{O}_{19}$ dengan konsentrasi doping $\mathrm{x}=0$ dan 2. Kurva histeresis menunjukkan bahwa nilai medan koersivitas menurun pada sampel dengan konsentrasi doping $\mathrm{x}=2$. Hasil penyerapan gelombang elektromagnetik menunjukkan bahwa sampel yang telah disubstitusi dengan ion $\mathrm{Ti}^{+4}$ dan $\mathrm{Zn}^{+2}$ (konsentrasi doping $\mathrm{x}=2$ ) memiliki puncak penyerapan tertinggi pada frekuensi $11,2 \mathrm{GHz}$ dengan nilai reflection loss (RL) sebesar -24,3 $\mathrm{dB}$. Penyerapan gelombang elektromagnetik setelah dihitung mencapai $94 \%$ dengan ketebalan sampel sekitar $1,0 \mathrm{~mm}$. Oleh karena itu, material magnetik $\mathrm{BaFe}_{12-\mathrm{x}} \mathrm{Ti}_{\mathrm{x} / 2} \mathrm{Zn}_{\mathrm{x} / 2} \mathrm{O}_{19}(\mathrm{x}=2)$ dapat digunakan untuk aplikasi penyerap gelombang elektromagnetik.
\end{abstract}

Kata-kata kunci: Substitusi, BaFe12-xTix/2Znx/2O19, wet milling, reflection loss, penyerap gelombang elektromagnetik.

\begin{abstract}
Substitution of $\mathrm{Ti}^{+4}$ and $\mathrm{Zn}^{+2}$ ions on magnetic material $\mathrm{BaFe}_{12-\mathrm{x}} \mathrm{Ti}_{\mathrm{x} / 2} \mathrm{Zn}_{\mathrm{x} / 2} \mathrm{O}_{19}(\mathrm{x}=0$ and 2) using the wet milling method has been performed. This research was conducted to get information the influence of Ti$\mathrm{Zn}$ substitution on magnetic properties and its absorption. The magnetic material BaFe12$\mathrm{xTix} / 2 \mathrm{Znx} / 2 \mathrm{O} 19$ is synthesized from a mixture of oxide materials, $\mathrm{BaCO}_{3}, \mathrm{Fe}_{2} \mathrm{O}_{3}, \mathrm{TiO}_{2}$ and $\mathrm{ZnO}$. The mixture was milled for 5 hours, dried at $100^{\circ} \mathrm{C}$ then sintered at $1000^{\circ} \mathrm{C}$ for 5 hours. The refinement result of the X-ray diffraction pattern shows that the sample has single phase $\mathrm{BaFe}_{12} \mathrm{O}_{19}$ with doping concentration of $x=0$ and 2 . The hysteresis curve shows that coercivity field value decreased in the sample with doping concentration of $x=2$. The result of electromagnetic wave absorption shows that the substituted sample with $\mathrm{Ti}^{+4}$ and $\mathrm{Zn}^{+2}$ ions (doping concentration $\mathrm{x}=2$ ) has the highest absorption peak at a frequency of $11,2 \mathrm{GHz}$ with reflection loss value (RL) of $-24,3 \mathrm{~dB}$. Electromagnetic wave absorption reaches $94 \%$ with sample thickness is about $1,0 \mathrm{~mm}$. Therefore, the magnetic material $\mathrm{BaFe}_{12-\mathrm{x}} \mathrm{Ti}_{\mathrm{x} / 2} \mathrm{Zn}_{\mathrm{x} / 2} \mathrm{O}_{19}(\mathrm{x}=2)$ can be used for application of the electromagnetic wave absorber.
\end{abstract}

Keywords: Substitution, $\mathrm{BaFe}_{12-\mathrm{x}} \mathrm{Ti}_{\mathrm{x} / 2} \mathrm{Zn}_{\mathrm{x} / 2} \mathrm{O}_{19}$, wet milling, reflection loss, electromagnetic wave absorber. 


\section{PENDAHULUAN}

Penggunaan frekuensi tinggi pada sistem elektronik menimbulkan fenomena electromagnetic interference (EMI) atau gangguan sinyal elektromagnetik sehingga menurunkan kinerja dari komponen elektronik [1]. Untuk mengatasinya diperlukan material untuk menyerap gelombang elektromagnetik tersebut. Gelombang elektromagnetik terdiri dari medan listrik dan medan magnet yang saling tegak lurus satu sama lain, sehingga material penyerap gelombang elektromagnetik dipengaruhi oleh adanya permitivitas (dielectric loss properties) dan permeabilitas (magnetic loss properties). Permitivitas merupakan ukuran efek medan listrik dalam gelombang elektromagnetik pada material sedangkan permeabilitas merupakan ukuran efek medan magnet dalam gelombang elektromagnetik pada material [2].

Salah satu material penyerap gelombang elektromagnetik yang sedang dikembangkan saat ini adalah material magnet berbasis barium heksaferit $\left(\mathrm{BaFe}_{12} \mathrm{O}_{19}\right)$. Barium heksaferit merupakan magnet permanen yang memiliki struktur heksagonal, nilai medan koersivitas, saturasi magnetisasi, permeabilitas, anisotropi yang tinggi serta stabilitas kimia yang baik $[2,3]$. Tingginya nilai koersivitas menyebabkan sifat anisotropiknya meningkat sehingga sifat penyerapannya menjadi lemah [4]. Keseluruhan interaksi penyerapan gelombang elektromagnetik diwakili oleh adanya impedance matching antara material $\left(\mathrm{Z}_{\text {in }}\right)$ dengan gelombang elektromagnetik $\left(\mathrm{Z}_{0}\right)$, sedangkan impedansi dipengaruhi oleh besarnya permeabilitas dan permitivitas material. Kondisi impedance matching terjadi jika $Z_{i n}=Z_{0}$ yang merepresentasikan sifat penyerapan yang sempurna [2]. Oleh karena itu, untuk meningkatkan kemampuan penyerapan gelombang elektromagnetik dari material barium heksaferit, diperlukan perbaikan sifat magnetik seperti koersivitas serta meningkatkan nilai permitivitasnya dengan mensubstitusi (doping) ion besi $\left(\mathrm{Fe}^{+3}\right)$ pada barium heksaferit dengan kation logam lain yang ukurannya hampir sama. Diketahui bahwa efisiensi doping tergantung pada perbedaan elektronegativitas dan jari-jari ionik antara dopan dan elemen tuan rumah $\mathrm{Fe}^{+3}$ [5].

Dalam penelitian ini, ion titanium $\left(\mathrm{Ti}^{+4}\right)$ dan seng $\left(\mathrm{Zn}^{+2}\right)$ dipilih sebagai dopan karena memiliki sifat diamagnetik, elektronegativitas dan jari-jari ionik yang hampir sama dengan ion $\mathrm{Fe}^{+3}$. Jari-jari ionik $\mathrm{Ti}^{+4}, \mathrm{Zn}^{+2}$ dan $\mathrm{Fe}^{+3}$ berturut-turut adalah 0,605 Angstrom $(\AA), 0,60 \AA$ dan $0,645 \AA$ sedangkan nilai elektronegativitas $\mathrm{Ti}^{+4}, \mathrm{Zn}^{+2}$ dan $\mathrm{Fe}^{+3}$ berturut-turut adalah 1,54, 1,7 dan 1,83 [5,6]. Substitusi ion $\mathrm{Fe}^{+3}$ dengan ion $\mathrm{Ti}^{+4}$ dan $\mathrm{Zn}^{+2}$ diharapkan dapat mengurangi sifat anisotropik dan menurunkan nilai medan koersivitas akibat dikacaukannya arah momen magnetik dari barium heksaferit dan dapat mengubah permitivitas dielektrik dan permeabilitas magnetiknya. Kehadiran ion $\mathrm{Ti}^{+4}$ dan $\mathrm{Zn}^{+2}$ juga diharapkan tetap mempertahankan struktur kristal dari barium heksaferit.

Pada penelitian ini, dilakukan studi tentang pengaruh substitusi ion Ti-Zn terhadap sifat kemagnetan dan sifat penyerapan gelombang elektromagnetik material sistem $\mathrm{BaFe}_{12-\mathrm{x}} \mathrm{Ti}_{\mathrm{x} / 2} \mathrm{Zn}_{\mathrm{x} / 2} \mathrm{O}_{19}$ (dengan konsentrasi doping $\mathrm{x}=0$ dan 2). Material ini disintesis menggunakan metode wet milling yang merupakan suatu metode reaksi padatan dengan memanfaatkan teknik milling secara basah. Pembentukan fasa material hasil sintesis diamati melalui pengujian menggunakan $X$-Ray Diffractometer (XRD). Sifat magnetik material diperoleh melalui pengujian menggunakan Vibrating Sample Magnetometer (VSM) dan sifat penyerapan gelombang elektromagnetik diamati pada rentang frekuensi antara 8 hingga $12 \mathrm{GHz}$ menggunakan Vector Network Analyzer (VNA).

\section{METODE PENELITIAN}

Substitusi ion $\mathrm{Fe}^{+3}$ dengan ion $\mathrm{Ti}^{+4}$ dan $\mathrm{Zn}^{+2}$ menggunakan rumus molekul $\mathrm{BaFe}_{12-\mathrm{x}} \mathrm{Ti}_{\mathrm{x} / 2} \mathrm{Zn}_{\mathrm{x} / 2} \mathrm{O}_{19}$ (dengan konsentrasi doping $\mathrm{x}=0$ dan 2) dilakukan menggunakan metode wet milling dengan total massa bahan 10 gram. Bahan utama yang digunakan adalah barium karbonat $\left(\mathrm{BaCO}_{3}\right)$, besi oksida $\left(\mathrm{Fe}_{2} \mathrm{O}_{3}\right)$, titanium oksida $\left(\mathrm{TiO}_{2}\right)$ dan seng oksida $(\mathrm{ZnO})$. Massa masing-masing bahan tersebut ditentukan berdasarkan perhitungan stoikiometri kemudian dicampur dan diletakkan ke dalam vial untuk masing-masing variasi konsentrasi doping (terdapat 2 sampel). Masing-masing campuran ditambahkan etanol dan bola mill dengan perbandingan massa antara material dan bola mill adalah 1:2. Campuran tersebut kemudian dimilling selama 5 jam menggunakan high energy milling (HEM). Campuran yang sudah dimilling kemudian dikeringkan pada suhu $100^{\circ} \mathrm{C}$ menggunakan oven. Setelah itu disintering pada suhu $1000^{\circ} \mathrm{C}$ selama 5 jam menggunakan furnace. 
Material magnetik yang telah terbentuk dikarakterisasi menggunakan XRD pada $2 \theta$ dari $20^{\circ}$ hingga $80^{\circ}$ menggunakan radiasi $\operatorname{CuK} \alpha(\lambda=0,154 \mathrm{~nm})$ untuk mengetahui fasa yang terbentuk. Sifat magnetik diketahui melalui kurva histerisis yang dihasilkan dari pengukuran menggunakan VSM dan sifat penyerapan gelombang elektromagnetik sampel diukur menggunakan VNA pada rentang frekuensi dari 8 hingga $12 \mathrm{GHz}$.

\section{HASIL DAN PEMBAHASAN}

Ion $\mathrm{Fe}^{+3}$ pada barium heksaferit disubstitusi dengan ion $\mathrm{Ti}^{+4}$ dan $\mathrm{Zn}^{+2}$ melalui metode wet milling, disintering pada suhu $1000^{\circ} \mathrm{C}$ selama 5 jam membentuk material atau sampel $\mathrm{BaFe}_{12} \mathrm{O}_{19}(\mathrm{x}=0)$ dan sampel $\mathrm{BaFe}_{10} \mathrm{TiZnO}_{19}(\mathrm{x}=2)$. Sebelum mengukur sifat magnetik dan sifat penyerapan kedua sampel tersebut, sampel dikarakterisasi menggunakan XRD yang kemudian dianalisa secara kualitatif dan kuantitatif. Analisa kualitatif dilakukan untuk mengidentifikasi fasa yang terbentuk pada sampel sedangkan analisa kuantitatif dilakukan untuk menghitung parameter kisi kristal. Proses identifikasi fasa didasarkan pada pencocokkan pola difraksi sinar- $X$ hasil eksperimen atau pola diraksi sinar-X observasi dengan pola difraksi sinar- $\mathrm{X}$ kalkulasi fasa $\mathrm{BaFe}_{12} \mathrm{O}_{19}$ standar yang ada dalam program Match. Gambar 1 menunjukkan pola difraksi sinar-X sampel $\mathrm{BaFe}_{12} \mathrm{O}_{19}(\mathrm{x}=0)$ dan sampel $\mathrm{BaFe}_{10} \mathrm{TiZnO}_{19}(\mathrm{x}=2)$.

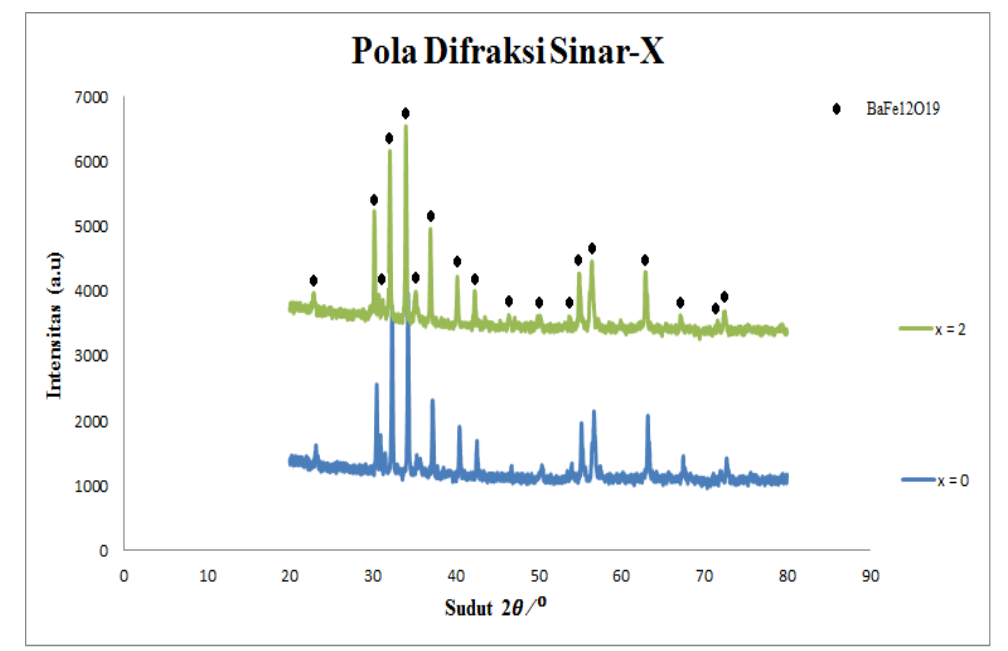

GAMBAR 1. Pola difraksi sinar- $\mathrm{X}$ sampel $\mathrm{BaFe}_{12} \mathrm{O}_{19}(\mathrm{x}=0)$ dan sampel $\mathrm{BaFe}_{10} \mathrm{TiZnO}_{19}(\mathrm{x}=2)$.

Dari hasil pola difraksi sinar-X ditunjukkan bahwa sampel dengan konsentrasi doping $\mathrm{x}=0$ dan $\mathrm{x}=2$ memiliki fasa tunggal $\mathrm{BaFe}_{12} \mathrm{O}_{19}$ sesuai dengan Crystallography Of Database (COD: 96-9008138) dalam perangkat lunak Match. Hal ini ditandai dengan tidak ditemukannya puncak asing sehingga substitusi ion $\mathrm{Ti}^{+4}$ dan $\mathrm{Zn}^{+2}$ ke dalam ion $\mathrm{Fe}^{+3}$ telah berhasil dilakukan.

Namun hasil dari identifikasi fasa berdasarkan program Match belum memberikan informasi struktur kristal dari sampel tersebut, untuk itu diperlukan analisis lebih lanjut menggunakan program General Structure Analysis System (GSAS) yang bertujuan untuk mengetahui perubahan parameter struktur dari fasa-fasa yang terbentuk pada sampel. Gambar 2 menunjukkan hasil refinement pola difraksi sinar- $\mathrm{X}$ sampel $\mathrm{BaFe}_{12} \mathrm{O}_{19}(\mathrm{x}=0)$ menggunakan GSAS. 


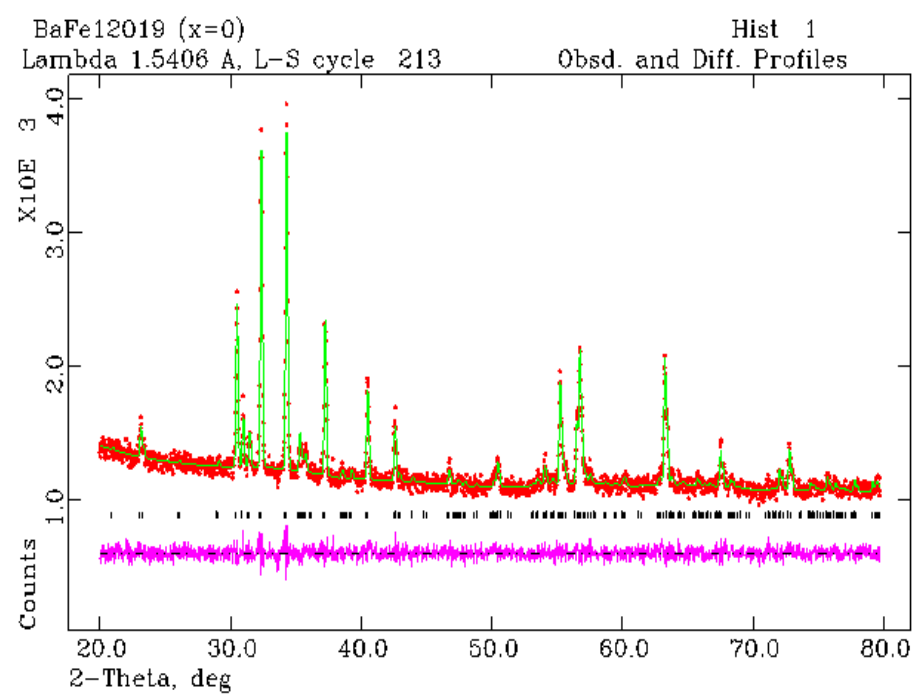

GAMBAR 2. Refinement pola difraksi sinar- $\mathrm{X}$ sampel $\mathrm{BaFe}_{12} \mathrm{O}_{19}(\mathrm{x}=0)$. Parameter statistik $\chi^{2}=1,231$, wRp $=3,16 \%$ dan $\mathrm{Rp}=2,51 \%$.

Kurva berwarna merah merupakan pola difraksi sinar-X hasil eksperimen yang disebut dengan pola difraksi sinar-X observasi. Kurva berwarna hijau merupakan pola difraksi sinar-X berdasarkan hasil perhitungan data referensi. Kurva berwarna hitam menunjukkan puncak-puncak yang terbentuk dari pola difraksi sinar-X hasil kalkulasi. Kurva berwarna ungu merupakan selisih antara pola difraksi sinar-X observasi dan kalkulasi. Posisi puncak observasi sudah sesuai dengan posisi puncak hasil kalkulasi sehingga selisih antara hasil observasi dengan hasil kalkulasi sangat kecil dengan demikian dapat dikatakan bahwa sampel telah terfitting dengan baik. Kualitas fitting dipengaruhi oleh faktor $\mathrm{R}$ yang terdiri dari nilai Weighting Ratio Profile ( $\mathrm{wRp}$ ) dan Ratio Profile ( $\mathrm{Rp}$ ) dengan rentang $\leq 10 \%$ serta nilai chi squared $\left(\chi^{2}\right)$ maksimum yang diperkenankan adalah sebesar 1,3 [7].

Berdasarkan hasil refinement pola difraksi sinar-X diperoleh bahwa sampel $\mathrm{x}=0$ memiliki fasa tunggal $\mathrm{BaFe}_{12} \mathrm{O}_{19}$ karena belum disubstitusi oleh ion $\mathrm{Ti}^{+4}$ dan $\mathrm{Zn}^{+2}$. Sampel memiliki struktur heksagonal dengan grup ruang P 63/m m c, parameter kisi $a=b=5,883828 \AA$ dan $c=23,171457 \AA$, $\alpha=\beta=90^{\circ}$ dan $\gamma=120^{\circ}$, Volume $(\mathrm{V})=694,711 \AA^{3}$ dan rapat jenis $\rho=12,219$ gr. $\mathrm{cm}^{-3}$. Gambar 3 menunjukkan hasil refinement pola difraksi sinar-X sampel $\mathrm{BaFe}_{10} \mathrm{TiZnO}_{19}(\mathrm{x}=2)$.

Berdasarkan hasil refinement pola difraksi sinar-X diperoleh bahwa sampel $\mathrm{x}=2$ juga memiliki fasa tunggal $\mathrm{BaFe}_{12} \mathrm{O}_{19}$, hal ini ditandai dengan tidak ditemukannya puncak asing. Sampel memiliki struktur heksagonal dengan grup ruang $\mathrm{P} 63 / \mathrm{m} \mathrm{m} \mathrm{c}$, parameter kisi $a=b=5,8906 \AA$ dan $c=$ $23,195194 \AA, \alpha=\beta=90^{\circ}$ dan $\gamma=120^{\circ}, \mathrm{V}=697,024 \AA^{3}$ dan $\rho=11,72$ gr.cm ${ }^{-3}$. Substitusi ion $\mathrm{Fe}^{+3}$ dengan ion $\mathrm{Ti}^{+4}$ dan $\mathrm{Zn}^{+2}$ tidak mengubah struktur kristalnya. 


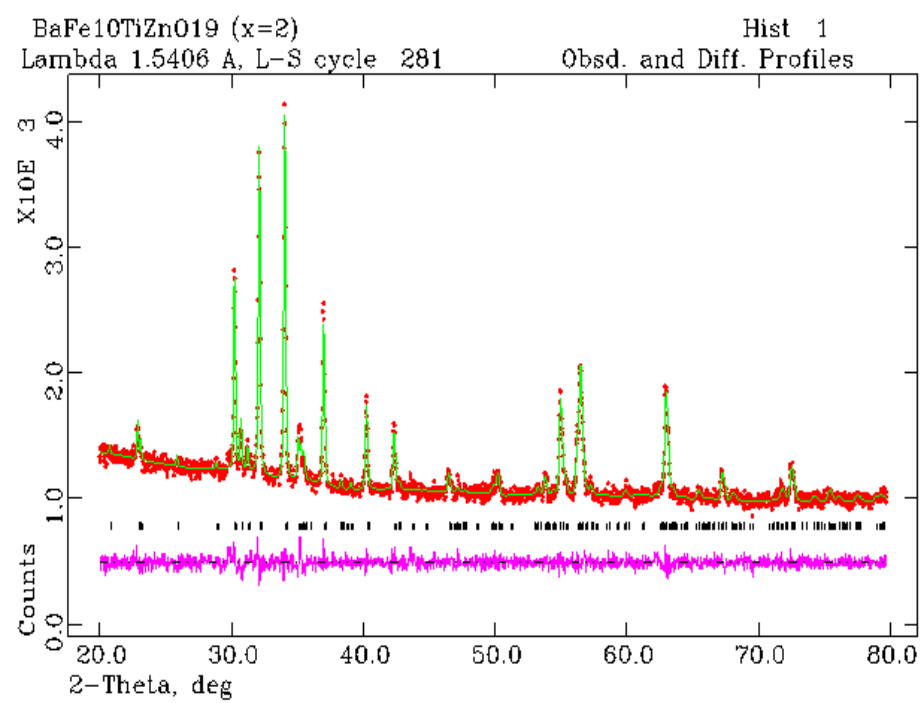

GAMBAR 3. Refinement pola difraksi sinar-X sampel $\mathrm{BaFe}_{10} \mathrm{TiZnO}_{19}(\mathrm{x}=2)$. Parameter statistik $\chi^{2}=1,284$,

$$
\mathrm{wRp}=3,30 \% \text { dan } \mathrm{Rp}=2,61 \% .
$$

Untuk mengetahui sifat kemagnetan dari sampel, dapat dilihat melalui kurva histerisis. Dari kurva tersebut dapat diketahui besarnya magnetisasi remanen $(\mathrm{Mr})$, medan koersivitas $(\mathrm{Hc})$ dan magnetisasi saturasi (Ms).

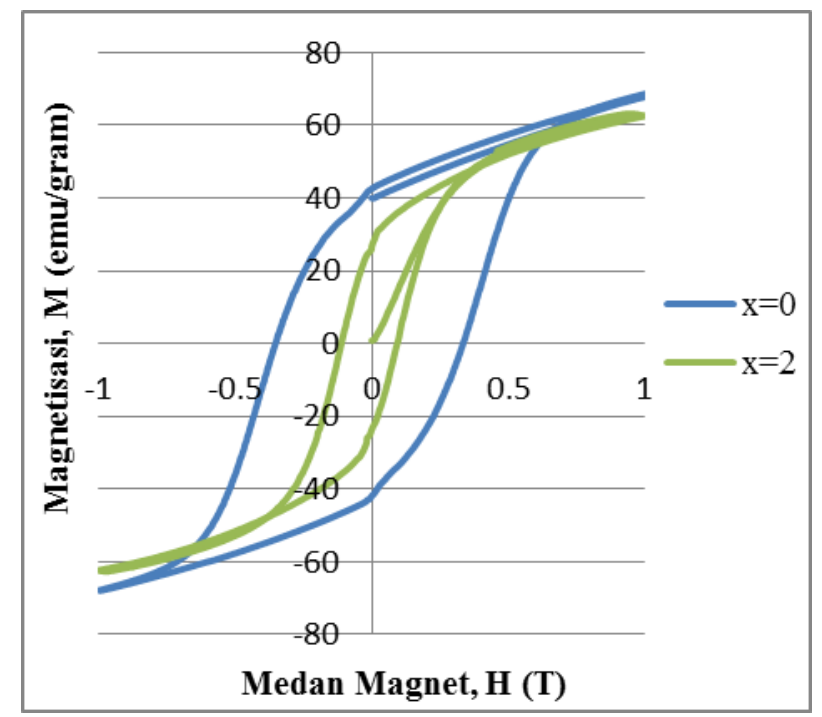

GAMBAR 4. Kurva histerisis sampel $\mathrm{BaFe}_{12} \mathrm{O}_{19}(\mathrm{x}=0)$ dan $\mathrm{BaFe}_{10} \mathrm{TiZnO}_{19}(\mathrm{x}=2)$.

Pada gambar 4 diperlihatkan perubahan lebar kurva histerisis. Ketika medan magnet luar $\mathrm{H}$ diberikan pada sampel $\mathrm{x}=0$, dipol magnetik akan bergerak mengikuti arah medan magnet luar $\mathrm{H}$ hingga mencapai titik jenuh dimana semua dipol magnetik sudah searah dengan medan magnet luar yang diberikan. Kondisi ini disebut magnetisasi saturasi (Ms) [8] yang diketahui nilainya melalui kurva histerisis pada gambar 4, sebesar 68,6 emu/gr. Kemudian ketika intensitas medan magnet luar $\mathrm{H}$ diturunkan hingga mencapai $\mathrm{H}=0$, terdapat sisa fluks magnet yang disebut magnetisasi remanen (Mr) [8] yang dalam kurva diketahui mempunyai nilai Mr sebesar 42,7 emu/g. Untuk menghilangkan sisa fluks magnet $(\mathrm{M}=0)$ tersebut membutuhkan medan balik atau disebut medan koersivitas $(\mathrm{Hc})$ [8]. Berdasarkan informasi dari kurva, nilai Hc sampel $\mathrm{x}=0$ adalah 0,3524 Tesla atau setara dengan 3524 Oersted sehingga bentuk kurva menjadi lebih lebar. Kondisi seperti ini membuat gelombang elektromagnetik sulit berinteraksi dengan momen magnet yang terdapat pada sampel $\mathrm{x}=0$ dikarenakan momen magnet yang kaku sehingga ketika gelombang elektromagnetik melewati sampel 
tersebut tidak terjadi resonansi yang mengakibatkan gelombang elektromagnetik tersebut tidak terperangkap dalam sampel $\mathrm{x}=0$.

Terjadi penurunan nilai medan koersivitas pada sampel $\mathrm{x}=2$ karena berubahnya momen magnet $\mathrm{Fe}^{+3}$ setelah adanya ion $\mathrm{Ti}^{+4}$ dan $\mathrm{Zn}^{+2}$. Nilai Hc sampel $\mathrm{x}=2$ adalah 0,1432 Tesla atau setara dengan 1432 Oersted, nilai Mr dan Ms berubah berturut-turut sebesar 31,8 emu/gr, 62,8 emu/gr. Hanya butuh medan balik sebesar 1432 Oersted untuk menghilangkan sisa fluks magnet yang terdapat pada material akibat pemberian medan magnet luar. Hal ini menyebabkan kurva histerisis sampel $\mathrm{x}=2$ memiliki bentuk yang lebih pipih dibandingkan dengan sampel $\mathrm{x}=0$.

Sifat penyerapan gelombang elektromagnetik diukur menggunakan VNA dan akan menghasilkan data keluaran parameter hambur (scattering parameter) atau gambaran "perilaku" refleksi $\left(\mathrm{S}_{11}\right)$ dan transmisi $\left(\mathrm{S}_{21}\right)$ yang terjadi pada dua port VNA. Dari parameter yang dihasilkan, dapat dihitung nilai reflection loss (RL) dengan menggunakan persamaan [9];

$$
R L=20 \log \left|S_{11}\right|
$$

Dengan $\left|S_{11}\right|=$ koefisien refleksi

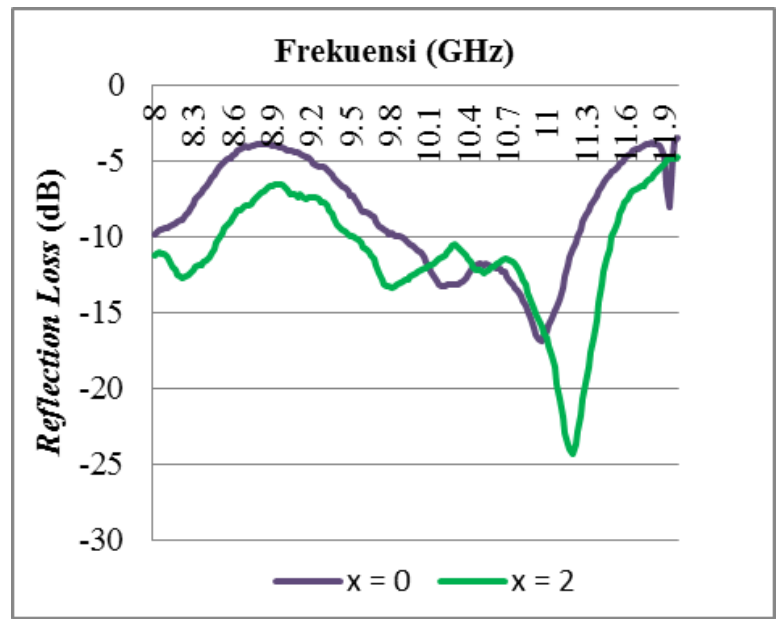

GAMBAR 5. Kurva reflection loss sampel $\mathrm{BaFe}_{12} \mathrm{O}_{19}(\mathrm{x}=0)$ dan $\mathrm{BaFe}_{10} \mathrm{TiZnO}_{19}(\mathrm{x}=2)$.

Berdasarkan kurva reflection loss pada gambar 5, sampel dengan konsentrasi doping $\mathrm{x}=0$ memiliki nilai RL sebesar $-16,9 \mathrm{~dB}$ pada frekuensi $11 \mathrm{GHz}$ sehingga dapat menyerap gelombang elektromagnetik sebesar $86 \%$. Ketika ion $\mathrm{Fe}^{+3}$ disubstitusi dengan ion $\mathrm{Ti}^{+4}$ dan $\mathrm{Zn}^{+2}($ sampel $\mathrm{x}=2$ ), nilai RL bertambah menjadi $-24,3 \mathrm{~dB}$ pada frekuensi $11,2 \mathrm{GHz}$ sehingga dapat menyerap gelombang elektromagnetik sebesar 94\% dengan ketebalan sampel sekitar 1,0 mm. Daerah serapan gelombang elektromagnetik pada sampel $\mathrm{x}=2$ lebih panjang dan lebih merata dibandingkan dengan sampel $\mathrm{x}=0$.

\section{SIMPULAN}

Substitusi ion $\mathrm{Ti}^{+4}$ dan $\mathrm{Zn}^{+2}$ pada material magnetik $\mathrm{BaFe}_{12-\mathrm{x}} \mathrm{Ti}_{\mathrm{x} / 2} \mathrm{Zn}_{\mathrm{x} / 2} \mathrm{O}_{19} \quad(\mathrm{x}=0$ dan 2$)$ menggunakan metode wet milling telah berhasil dilakukan. Berdasarkan hasil analisis fasa profil XRD menggunakan GSAS menunjukkan bahwa sampel $\mathrm{x}=0$ dan $\mathrm{x}=2$ memiliki fasa tunggal $\mathrm{BaFe}_{12} \mathrm{O}_{19}$. Menurut hasil analisa sifat magnetik diperoleh nilai medan koersivitas menurun setelah ion $\mathrm{Fe}^{+3}$ disubstitusi dengan ion $\mathrm{Ti}^{+4}$ dan $\mathrm{Zn}^{+2}$. Medan koersivitas yang kecil dapat meningkatkan sifat penyerapan gelombang elektromagnetik. Sedangkan hasil pengukuran kemampuan penyerapan gelombang elektromagnetik terbesar didapatkan pada konsentrasi doping $\mathrm{x}=2\left(\mathrm{BaFe}_{10} \mathrm{TiZnO}_{19}\right)$ dengan reflection loss sebesar $-24,3 \mathrm{~dB}$ pada frekuensi 11,2 GHz. Dengan demikian, material $\mathrm{BaFe}_{10} \mathrm{TiZnO}_{19}$ merupakan salah satu kandidat material penyerap gelombang elektromagnetik. 


\section{UCAPAN TERIMAKASIH}

Ucapan terima kasih penulis sampaikan kepada Badan Tenaga Nuklir Nasional (Batan) atas bantuan dalam penyediaan laboratorium dan penggunaan peralatan untuk pengukuran, yang digunakan selama proses penelitian dan kepada Lembaga Ilmu Pengetahuan Indonesia (LIPI) atas fasilitas untuk pengukuran.

\section{REFERENSI}

[1] A. Joshi, S. Datar, "Carbon nanostructure composite for electromagnetic interference shielding," Journal of physics, 2015, vol. 84, pp. 1099-1116.

[2] A. A. Wisnu, "Pengembangan bahan magnetik sistem $\mathrm{La}_{(1-\mathrm{y})} \mathrm{Ba}_{\mathrm{y}} \mathrm{Fe}_{\mathrm{x}} \mathrm{Mn}_{1 / 2(1-\mathrm{x})} \mathrm{Ti}_{1 / 2(1-\mathrm{x})} \mathrm{O}_{3}(\mathrm{x}=0$ $1,0$ dan y $=0-1,0)$ sebagai bahan penyerap gelombang elektromagnetik", Disertasi, FMIPA, Universitas Indonesia, 2012.

[3] Z. Mosleh, P. Kameli, A. Poorbaferani, M. Ranjbar, H. Salamati, "Structural, magnetic and microwave absorption properties of Ce-doped barium hexaferrite", Department of Physics, Isfahan University of Technology, Isfahan 84156-83111, Iran, 2015.

[4] A. Desyani, E. Handoko, M.A. Marpaung, "Struktur dan Sifat Kemagnetan Material Magnet $\mathrm{BaFe}_{12} \mathrm{Mn}_{\mathrm{x}} \mathrm{Zn}_{\mathrm{x}} \mathrm{O}_{19}$ yang Disiapkan dengan Metode Ultrasonic Mixing". Prosiding Pertemuan Ilmiah XXVIII HFI Jateng \& DIY, Yogyakarta, 2014, ISSN: 0853-0823.

[5] G.C. Xie, L. Fang, L. P. Peng, G.B. Liu, H. B. Ruan, F. Wu, C.Y. Kong, "Effect of In-doping on the optical constants of $\mathrm{ZnO}$ thin films". Physics Procedia 32, 2012, pp. 651-657.

[6] J. Li, H. Zhang, V. G. Harris, Y. Liao, Y. Liu, "Ni-Ti equiatomic co-substitution of hexagonal M-type $\mathrm{Ba}(\mathrm{NiTi})_{\mathrm{x}} \mathrm{Fe}_{12-2 \mathrm{x}} \mathrm{O}_{19}$ ferrites". Journal of Alloys and Compounds 649, 2015, pp. 782-787.

[7] A. A. Wisnu, A. Manaf, "Structural and Absorption Characteristics of Mn-Ti Substituted BaSr Hexaferrite Sythesized by Mechanical Alloying Route". Journal of Basic and Applied Scientific Research, 2012, ISSN 2090-4304.

[8] Jr. W. D. Calister, Fundamentals of Materials Science and Engineering, 2000.

[9] A. Syamsir, Astuti, "Sintesis Nanokomposit PAni/ $\mathrm{TiO}_{2} /$ Karbon Sebagai Penyerap Gelombang Mikro". Jurnal Fisika Unand, 2012, Vol. 1, No. 1. ISSN 2302-8491. 
